\title{
The Impact of Managers Overconfidence on Corporate Investment
}

\author{
Xiao Longjie and Zhou Anfeng
}

\begin{abstract}
In recent years, the phenomenon of inefficient investment of listing Corporation in our country is serious. Excessive investment behavior is one of the important reasons that lead to ineffective investment. Under the influence of behavioral finance, the research of corporate finance begins to pay attention to the influence of managers over confidence on the investment behavior of enterprises. For a long time, an empirical study on the relationship between managerial over confidence and firm investment behavior has been lagging behind the development of the theory. This paper takes the $A$ shares of non financial listing Corporation from 2009 to 2011 as the research sample. The relationship between managerial over confidence and over investment of enterprise is studied by using the deviation of enterprise profit forecasting as an alternative variable of manager's over confidence. Based on the expected investment model to estimate the enterprise over investment spending. The following conclusions are obtained through empirical research: Investor over confidence and listing Corporation over investment level is positive correlation.
\end{abstract}

Index Terms-Overconfidence, over-investment, behavioral finance.

\section{INTRODUCTION}

Modern Corporation's financial theory implies the assumption of rational people. In recent years, the rise of behavioral finance has challenged the assumption. The research of corporate finance has also begun to pay attention to the influence of managers' irrational behavior on the investment behavior of enterprises under the influence of behavioral finance. Over confidence is one of the many forms of performance of managers. Overconfidence is originally a term in cognitive psychology. Psychologists believe that people in the future often show overconfidence. Overconfidence in behavioral finance theory is a kind of the most important psychological deviation. It refers to people's excessive optimism about their ability, knowledge and future predictions. They believe that their knowledge is more accurate than the facts, that is, the weight of their own information is greater than the weight of the fact. Over confidence is often expressed as the possibility of decision makers to overestimate the expected return or the likelihood of success, to underestimate the cost and the probability of failure.

As early as 1986, Roll analysis of the impact of over confident managers on corporate mergers and acquisitions.

Manuscript received May 11, 2016; revised August 6, 2016.

The authors are with Nanjing University of Aeronautics \& Astronautics, China (e-mail: xiaolj007@nuaa.edu.cn, zaf@nuaa.edu.cn).
Heaton (2002) proposed a based on Managerial Overconfidence of alienation of investment model. This model combines managers' over confidence and free cash flow variables. It is derived that under the different free cash flow managers over confidence will lead to excessive investment and insufficient investment [1]. Gervais et al. (2003) developed a capital budgeting model to study the effects of managerial over confidence on corporate investment policy and the role of stock option plans. Malmendier et al. (2005) carried out an empirical test on the theory of Heaton (2002). They first pioneered the use of CEO ownership status of this variable to measure managers over confidence and an empirical test. Lin et al. (2005) used a similar method to test the data in Taiwan. They use corporate earnings forecasts to measure the deviation of variables to measure managers over confidence [2].

However, in our country, many variables cannot be used as an alternative to the manager's over confidence to study the influence of managerial over confidence on enterprise investment. Since the implementation of equity incentive in China's listing Corporation is relatively small and is not mature, so the stock option is not applicable to this measure. The relevant information, data acquisition difficulties, media reports, earnings forecasts and consumer sentiment index are not suitable for the actual situation in china. Business climate index although easy to obtain, but it represents the degree of confidence in an industry all entrepreneurs. It is also not an ideal indicator, because it does not represent a specific enterprise managers on the industry and the company's business development outlook. Hao Ying et al. (2005) used CEO holdings as variables to measure managers over confidence [3]. Wang Xia et al. (2007) used CEO ownership and corporate earnings forecast deviation variables to measure the manager (Chairman) over confident [4]. Jiang Fuxiu et al. (2009) used the enterprise earnings forecast deviation and the relative return variable of CEO to measure the manager's over confidence [5]. For a long time, the empirical research on the relationship between managerial over confidence and corporate investment behavior has been lagging behind the development of the theory. It is difficult to find a suitable substitute variable to measure the manager's over confidence. Based on this, by taking the enterprise earnings forecast deviation as an alternative to measure whether managers are over confident and empirical analysis of the impact of managerial over confidence on corporate investment.

\section{THE THEORETICAL STUDY OF OVER CONFIDENCE AND OVER INVESTMENT}

\section{A. The Connotation and Manifestation of over Confidence}

Maintaining proper confidence in social life is a 
necessary condition for individuals to adapt to the environment and enhance the ability of self survival. Over confidence is a kind of limited rationality or irrationality. A considerable portion of the population has self central characteristics. They always overestimate their knowledge and abilities. They believe that their own information and related judgments and decisions are better than the general level. At present, there is no uniform definition of the behavior of corporate finance. Some scholars have defined over self-confidence as a psychological bias that is too high to estimate a series of events. [6].

Overconfidence usually in two forms: first, a valuation of the confidence intervals that are too narrow. Fischhof, Slovic and Lichtenstein found that excessive confidence comes from people of probability of occurrence mistake estimation. The result is forecast uncertainty event accuracy is overrated. The possibility of occurrence of small probability events is estimated to be too high and that it is always possible. For more than $90 \%$ of the probability of events that will happen, that is, the estimated confidence interval is too small. For example, they estimate that $98 \%$ of the confidence interval is actually only the true number of $60 \%$ [7]. Second, the ability to estimate the event probability is poor, and the probability that the event may occur is much higher than the probability that the event will occur. However, the probability that the event is not likely to occur is much lower than the probability of its occurrence. For example: Slovic, Fischhof and Lichtenstein (1977) found that there are only $80 \%$ of the events that people think will happen. But people don't think it's possible that the event actually occurred in $20 \%$ [8].

\section{B. Measure of over Confidence}

Up to now, there are seven main variables used in the study of over confidence in China and abroad, which are the following variables [9]:

1) CEO shareholding status.

2) The evaluation of related mainstream media to CEO.

3) Enterprise earnings forecast deviation.

4) CEO the frequency of the implementation of mergers and acquisitions.

5) Relative return of CEO.

6) Current performance of Merger and Acquisition Enterprises

7) Business climate index.

In this paper, we use the enterprise earnings forecast deviation as an alternative manager to study the over confidence of the variables to conduct research from the perspective of corporate finance. According to listing Corporation 2009 to 2011 annual results notice changes to measure whether the listing Corporation's managers over confidence. At the same time, in accordance with the degree of deviation of the forecast to quantify the degree of the degree of confidence of managers.

\section{Theoretical Research on over Investment of Enterprises}

\section{1) Definition of excessive investment}

The investment behavior of the enterprise is enterprise growth and future cash flow growth. Corporate investment efficiency is directly related to whether the enterprise growth and development. However, the reality of all kinds of signs that the listing Corporation's investment behavior often can not bring the value of enterprises. This kind of investment is a kind of inefficient investment, and over investment is one of them. [10]. There are two definitions of over investment: the first is the scale of investment and free cash flow to be compared. The second is to compare the actual amount of investment and the ideal investment.

\section{2) Interpretation of traditional finance}

The main research of corporate finance is the management of the company and the investors in the company's investment and financing decisions in the process of achieving the objectives of the company. From a long-term point of view, the study on financial companies are established no partial projections in the rational assumption. It assumes that there is an unbiased forecast of future events, and uses these projections to make decisions that maximize their benefits. Traditional finance believes that the managers of listing Corporation think that the capital market is effective. The price of the securities of the company can reflect all the information that is related to the basic value of the company. However, investors in the market also believe that the managers of the company will make rational decisions to the company in order to achieve the goal of maximizing their interests.

\section{3) Behavioral finance interpretation}

The rise and development of behavioral finance provides a new perspective for the study of over investment behavior of enterprises. Behavioral finance argues that people tend to be vulnerable to the effects of psychological factors such as emotional and bias in their behavior, resulting in a deviation from optimization. Behavioral corporate finance is based on the assumption that the more realistic, the better explain the listing Corporation investment decisions. Assuming that the managers of the listing Corporation are rational and investors are irrational. Investors include ordinary investors and institutional investors. Then the non rational investors will affect the investment decision of the listing Corporation.

\section{Measure of over Investment}

\section{1) The measurement method of over investment}

There are a lot of researches on the excessive investment of enterprises, both at home and abroad. But the alternative indicators used to measure the degree of excessive investment are different. At present, the more widely used include marginal Tobin Q model, Vogt model, Richardson model and Wurgler model.

Tobin Q model's contribution is to determine the size of the investment is no longer dependent on past economic variables but the expectations of the future. In Vogt (1994) model, the interaction between cash flow and investment opportunity is put into the investment model. And then according to the regression results in the coefficient of the interaction term to determine the direction of the company is to judge whether the performance of excessive investment or investment [11]. In the Richardson (2006) model, over investment is defined as the excess investment expenditure on the basis of the new investment projects that are positive for the capital and net present value of the enterprise. This 
model believes that the company's new investment spending is mainly composed of two parts: expected investment expenditures and non normal investment expenditures of the company. In the regression results of the model, residual term reflects the company's inefficient investment level [12].

\section{2) The measurement method of over investment in this paper}

This paper will use Richardson (2006) to calculate the over investment. I will take the company's purchase and construction of fixed assets, intangible assets and other long-term assets paid cash, made of subsidiaries and other business units to pay cash, investment expenditures paid cash and with the ratio of total assets at the beginning of the year as a total investment [13]. Total investment can be decomposed into two parts: first part, investment in a new positive NPV projects expected spending It; the second part, additional investment over (over investment spending). In the end, the company's excessive investment is expressed by the difference between the actual capital investment level and the expected capital investment level. (regression residuals)

\section{RESEARCH DESIGN}

\section{A. Research on over Investment}

First of all, this paper estimates the investment expectation model to estimate the company's over investment expenditure. The results of this model are used to calculate the expected new investment expenditure and excessive investment. The factors that affect the investment expenditure of the company include the growth opportunities, financing constraints, the level of cash holdings, the age of listing, the size of the company, and so on. According to the above factors, model I is as follows:

$$
\begin{gathered}
\mathrm{I}_{\mathrm{t}}=\beta_{0}+\beta_{1} \text { grow }+\beta_{2} \mathrm{lev}+\beta_{3} \text { age }+\beta_{4} \mathrm{cash}+ \\
\beta_{5} \text { size }+\beta_{6} \mathrm{I}_{\mathrm{t}-1}+\xi
\end{gathered}
$$

(1) Research variables

1) Total investment: Is the company's first t years' amount of build fixed assets, Cash paid for intangible assets and other long-term assets, Cash paid by subsidiaries and other business units, cash paid for investment and the ratio of assets to total assets at the beginning of $t$.

2) Growth opportunities: Use the company's main business income to measure.

3) Asset liability ratio: Is the ratio of average total assets in the beginning of the end of the average of total liabilities to company at the end of the early years.

4) Company size: The average total assets at the end of the year was used to measure the company.

5) Cash holdings: The average ratio of the average total assets in the beginning of the end of the company's year end cash balances.

6) Age of listing: Listed age from the date of announcement of the company from the date of listing.
7) The previous period investment: As the effect of elimination of annual values of control variables on regression results. Is the ratio of the company over investment and average total assets at the end of the year early last year the company.

\begin{tabular}{|c|c|c|}
\hline Variable code & Variable name & Variable description \\
\hline It & Total investment & $\begin{array}{l}\text { It equals Investment amount } \\
\text { divide Total assets at the end of } \\
\text { last year }\end{array}$ \\
\hline grow & $\begin{array}{l}\text { Growth } \\
\text { opportunities }\end{array}$ & $\begin{array}{l}\text { Grow equals Main business } \\
\text { income of the year reduceLast } \\
\text { year's main business income } \\
\text { divide Last year's main business } \\
\text { income }\end{array}$ \\
\hline lev & $\begin{array}{l}\text { Asset liability } \\
\text { ratio }\end{array}$ & $\begin{array}{l}\text { Lev equals average debt divide } \\
\text { average assets }\end{array}$ \\
\hline size & Company size & Size equals average assets \\
\hline cash & Cash holdings & $\begin{array}{l}\text { Cash equals average cash balances } \\
\text { divide average assets }\end{array}$ \\
\hline age & Age of listing & $\begin{array}{l}\text { Age equals Listing announcement } \\
\text { date to this year }\end{array}$ \\
\hline
\end{tabular}

TABLE I: DESCRIPTION OF EACH VARIABLE IN THE MODEL I

(2) Sample selection and data sources

This paper selected interval of the sample from 2009 to 2011, the Shanghai stock market all listing Corporation issued A shares. In order to ensure the scientific nature of the research, according to the following criteria: 1) Excluding the annual ST and PT companies, the company's financial situation is abnormal, or has a continuous loss for two years or more, if these companies will affect the research results in the study sample; 2) Do not consider the financial listing Corporation, which is due to its own characteristics of the financial companies will be excluded from the sample; 3) Because of foreign shares and A shares of the stock price is different, for convenience, excluding the issue of $\mathrm{B}$ shares issued $\mathrm{B}$ shares, $\mathrm{H}$ shares, $\mathrm{N}$ shares of the company; 4) Companies that eliminate data missing; 5) Companies that only consider meeting the above conditions and the manager's over confidence. At last, the data obtained from 179 companies is removed 748 companies from 927 companies. The data from Resset database query system and stock investment software listed in the basic information. It was combined with the company's annual report and disclosure of information. All the statistical data are calculated by EXCEL software.

\section{B. The study on the Relationship between over Investment and over Confidence}

In this paper, the excessive investment value obtained by the regression analysis of the investment expectation model is used as the dependent variable. Then we examine the effect of managerial over confidence on the company's over investment by regression of each observed value. At the end, the relationship between managerial over confidence and over investment behavior of the company is analyzed. According to these, the model II is as follows:

$$
\text { over }=\beta_{0}+\beta_{1} \text { ocon }+\beta_{2} \text { scale }+\beta_{3} \text { idr }+\xi
$$

(1) Research hypothesis

At present, the research abroad on Managerial Overconfidence and investment behavior of listed 
companies is mainly concentrated on two aspects: one is theoretical research: roll (1986) used the manager's over confidence hypothesis to explain the reasons for the failure of the company's value in the event of $M \& A$ activities. Heaton (2002) thought that when there is free cash flow, over optimistic managers will overestimate the net present value of the investment project NPV, which will lead to over investment problems. Second, is an empirical study of: Odean (1998) study found, over confident managers tend to accept and engage in projects earlier, resulting in losses to the company. Sapienza and Polk (2002) found that, investors' excessive self-confidence leads to a listing Corporation with an over-estimated investment expenditure which is often more than the price of a normal reaction to the company's value. [14]. In China, to investors overconfidence and over investment of listed company research has just started, and mainly focused on the effects of overconfidence on the behavior of traders, and in terms of its impact on the corporate level, mainly to managers overconfidence and investment related research. Wang Xia et al. (2008) in their study found that the excessive confidence of managers are more likely to produce excessive investment tendency. So this paper, based on the relevant research results at home and abroad, from the perspective of behavioral finance, focuses on the impact of investor over confidence on the listing Corporation's over investment behavior [15]. Based on the above discussion, we put forward the following hypothesis:

$\mathrm{H}$ : Investor over confidence and listing Corporation over investment level is positive correlation

(2) Research variables

1) Over confidence: The use of enterprise earnings forecasts as an alternative to the managers of excessive self - confidence variables to conduct research. Quantify the extent of the manager's excessive confidence in the degree of deviation from its forecast.

2) Over investment: Regression residuals from the investment expectation model.

3) Company size: As the control variables of the model is the average total assets.

4) Governance structure: Control variables. Independent directors accounted for the proportion of the board of directors.

TABLE II: DESCRIPTION OF EACH VARIABLE IN THE MODEL II

\begin{tabular}{lll}
\hline $\begin{array}{l}\text { Variable } \\
\text { code }\end{array}$ & Variable name & Variable description \\
\hline over & Over investment & $\begin{array}{l}\text { The residuals from the regression } \\
\text { model of the investment } \\
\text { expectation model greater than zero }\end{array}$ \\
ocon & Over confidence & $\begin{array}{l}\text { Deviation degree of enterprise } \\
\text { earnings forecast deviation }\end{array}$ \\
scale & Company size & $\begin{array}{l}\text { Average total assets } \\
\text { idr }\end{array}$ \\
Governance & $\begin{array}{l}\text { Independent directors accounted for } \\
\text { the proportion of the board of } \\
\text { directors }\end{array}$ \\
\hline
\end{tabular}

(3) Sample selection and data sources

This paper selected interval of the sample from 2009 to 2011, the Shanghai stock market all listing Corporation issued A shares. In order to ensure the scientific nature of the research, according to the following criteria: 1) Excluding the annual ST and PT companies, the company's financial situation is abnormal, or has a continuous loss for two years or more, if these companies will affect the research results in the study sample; 2) Do not consider the financial listing Corporation, which is due to its own characteristics of the financial companies will be excluded from the sample; 3) Because of foreign shares and A shares of the stock price is different, for convenience, excluding the issue of B shares issued B shares, $\mathrm{H}$ shares, $\mathrm{N}$ shares of the company; 4) Companies that eliminate data missing; 5) Companies that only consider meeting the above conditions and the manager's over confidence. At last, the data obtained from 179 companies is removed 748 companies from 927 companies. The data from Resset database query system and stock investment software listed in the basic information. It was combined with the company's annual report and disclosure of information. All the statistical data are calculated by EXCEL software.

TABLE III: DESCRIPTIVE STATISTICS OF VARIABLES

\begin{tabular}{cccccc}
\hline & $\begin{array}{c}\text { Sample } \\
\text { quantity }\end{array}$ & $\begin{array}{c}\text { Minimu } \\
\text { m value }\end{array}$ & $\begin{array}{c}\text { Maximu } \\
\text { m value }\end{array}$ & $\begin{array}{c}\text { Mean } \\
\text { value }\end{array}$ & Variance \\
\hline It & 179 & 0.0001 & 1.2370 & 0.1375 & 5.5054 \\
It-1 & 179 & -0.0182 & 0.8285 & 0.1152 & 3.1816 \\
age & 179 & 1.0000 & 24.0000 & 13.5419 & 2274.4360 \\
grow & 179 & -0.9847 & 10.0000 & 0.6047 & 844.5158 \\
cash & 179 & 0 & 2.5461 & 0.1931 & 23.6237 \\
lev & 179 & 0.0123 & 1.1663 & 0.4565 & 7.3576 \\
size & 179 & 0.0526 & 179.1060 & 4.9432 & 35577.6300 \\
over & 53 & 0.0018 & 0.7738 & 0.0991 & 1.3614 \\
ocon & 53 & 0.0032 & 5.2989 & 0.2982 & 29.4633 \\
scale & 53 & 0.1304 & 27.2572 & 4.5516 & 1516.5040 \\
idr & 53 & 0.1611 & 0.5111 & 0.3434 & 0.3277 \\
\hline
\end{tabular}

\section{EMPIRICAL TEST AND ANALYSIS}

\section{A. Preliminary Statistical Description Analysis}

Table III reflects the descriptive statistical characteristics of the variables in the empirical test. The minimum value of over investment is 0.0018 , the maximum is 0.7738 , the average is 0.0991 , and the variance is 1.3614 ; The variance of managers' over confidence is 29.5112, and the big variance shows fluctuations is large; The minimum value of scale is 0.1304 , the maximum is 27.2572 , the mean value is 4.5516 , and the variance is 1516.5040 ; The minimum value of IDR is 0.1611 , the maximum is 0.5111 , the mean value is 0.3434 , and the variance is 0.3277 . Total investment (It), growth opportunities(grow), company size(size), asset liability ratio(lev), cash holdings(cash), age of listing (age), the investment (It-1) are the control variables in the expected investment model. Their descriptive characteristics are: The minimum value of It is 0.0001 , the maximum is 1.2370 , the mean value is 0.1375 , and the variance is 5.5054 ; The minimum value of It- 1 is -0.0182 , the maximum is 0.8285 , the mean is 0.1152 , the variance is 3.1816 ; The minimum value of grow is -0.9847 , the maximum is 10 , the mean is 0.6047 , the variance is 844.5158 ; The minimum 
value of size is 0.0526 , the maximum is 179.1060 , the mean value is 4.9432, and the variance is 35577.6300; The minimum value of Lev is 0.0123 , the maximum is 1.1663 , the mean value is 0.4565 , and the variance is 7.3576 ; The minimum value of cash is 0 , the maximum is 2.5461 , the mean value is 0.1931 , and the variance is 23.6237 ; The minimum value of age is 1 , the maximum is 24 , the mean value is 13.5419 , and the variance is 2274.4360 .

The observation value of the over confidence class was 156. About $9 \%$ of the total sample observation value was about 2084. This fully showed that the existence of the management of the listing Corporation in the case of excessive confidence. The mean value of overconfidence sample's increased investment value added $(\triangle \mathrm{I} / \mathrm{K})$ was 0.053 , the maximum value was 0.604 , the minimum value was 0.234 ,and the maximum value was similar to the non over - confidence samples, The mean of the non over confidence samples' increased investment value added $(\triangle$ $\mathrm{I} / \mathrm{K}$ ) was 0.026 and the minimum was 1.989 . The mean and the minimum of value of overconfidence sample's increased investment value added $(\triangle \mathrm{I} / \mathrm{K})$ were significantly higher than those. They are more $104.630 \mathrm{k}$ and $85.250 \mathrm{k}$ than the former. The above statistical results show that, there is the phenomenon of over-confidence of listing Corporation in our country. And the management of over confident Sample Firms relative to other Sample Firms. It's investment scale and investment level was higher. It showed that description of the size of the different Sample Firms there is a big difference, and other variables in different Sample Firms are relatively small.

\section{B. Measure of over Investment}

First, through investment expectation model we can measure the expected investment value. The residual error of the model is a measure of the enterprise's over investment. Table IV shows the values of the variables, the values of T, $\mathrm{DW}, \mathrm{F}$ and R2, which are derived from the regression analysis of the investment expectation model.

TABLE IV: THE REGRESSION ANALYSIS RESULTS OF MODEL I

\begin{tabular}{ccc}
\hline Independent variable & Coefficient & T value \\
\hline It & -0.0092 & -0.2243 \\
grow & 0.0073 & 1.8202 \\
cash & 0.0110 & 0.4589 \\
lev & 0.0359 & 0.8302 \\
size & -0.0005 & -0.8144 \\
age & 0.0009 & 0.3608 \\
It-1 & 0.9910 & 15.1374 \\
DW & 2.01 & \\
R2 & 0.57 & \\
F & 39.20 & \\
\hline
\end{tabular}

Generally, the fitting coefficient of equation was higher. It shows that the investment expectation model was more credible. And the DW test values of the model were very close to 2 . There was no correlation between the regression model and the regression model.

\section{The study on the Relationship between over Investment and over Confidence}

In order to reveal the relationship between managers' over confidence and investment, we test the hypothesis through theoretical analysis. We use statistical software EviewS6.0 and SPSS13.0. Regression analysis of the observed value of the 2084 companies involved in the 1042 Sample Firms. Considered the relationship between over investment and over confidence, we used over investment as a dependent variable. The explanatory variable is the measure of over confidence. It is in order to examine the effect of over confidence on the excessive investment behavior of enterprises.

The results of the analysis are shown in table $\mathrm{V}$. It reflected the model II by regression analysis of the variables of the system values, $t$ values, as well as the DW value, R2 value and $F$ value.

TABLE V: THE REGRESSION ANALYSIS RESULTS OF MODEL II

\begin{tabular}{ccc}
\hline Independent variable & Coefficient & T value \\
\hline over & 0.2741 & 2.6887 \\
ocon & 0.0484 & 1.2480 \\
idr & -0.4402 & -1.5332 \\
size & -0.0091 & -1.7221 \\
DW & 2.41 & \\
R2 & 0.09 & \\
F & 1.61 & \\
\hline
\end{tabular}

From the Table $\mathrm{V}$ we can see that the independent variable OCON changes 1 units, at the same time the dependent variable over changes 0.048 units. From the overall $\mathrm{R} 2$ value and $\mathrm{F}$ value, the equation has a certain degree of fitting. It is more believable, and the DW value is close to 2 , between 1.5 and 2.5 . It shows that the regression model does not have the problem of sequence correlation. It was not difficult to see from the results of the regression results. Over investment and over confidence were significant positive correlation. Managers over confidence index oc: coefficient was positive. The coefficient was significant at the 5\% level. This showed that there was a significant positive correlation between managers' over confidence and corporate investment. The greater the company's investment spending, the more confident the manager. Managerial Self-confidence had a positive impact on investment decisions. The managers over confident companies had higher investment levels than non-selfconfidence firms. As a result, the hypothesis presented in the previous paper has been proved to be effective.

\section{CONCLUSION}

This paper selects the interval from 2009 to 2011 Shanghai A shares of all non-financial listed companies as the initial sample. In this paper, the earnings forecast deviation as an alternative variable of over confidence, empirical test of the impact of investor over confidence on the behavior of listing Corporation over investment. The conclusions are as follows: investors' over confidence and listing Corporation over investment level is positive correlation. At the same time, the conclusion of this paper is to expand and enrich the existing listed companies investment behavior and the behavior financial theory research results. Practical significance: Impel the listed companies to adopt optimal investment decision to improve the intrinsic value of the company; Protect the vital interests of investors; Guide China's capital market stable and healthy; Sustainable development and improve macroeconomic policy makers on the regulatory efficiency of the listed 
companies.

\section{REFERENCE}

[1] J. Heaton, "Managerial optimism and corporate finance," Financial Management, vol. 31, pp. 33-45, 2002.

[2] G. Y. Zhu and Y. D. Shi, "An empirical study on managerial over confidence and the behavior of enterprise merger and acquisition," Financial Review, vol. 2, pp. 73-82, 2010.

[3] X. Wang and M. Zhang, "Managers over confidence in enterprise investment alienation," Finance and Accounting, vol. 2, pp. 77-83, 2008.

[4] F. S. Yu and S. Zhang, "Managerial over confidence and cost of equity capital," Audit and Economic Research, vol. 26, no. 1, pp. 72-80, 2011.

[5] Z. F. Lu and C. D. Chen, "Managers over confidence, corporate expansion and financial distress," Economic Research, vol. 1, pp. 131-143, 2009.

[6] J. W. Zhou, "A study on the relationship between managerial over confidence and capital structure of enterprises," Accounting Research, vol. 17, pp. 56-59, 2011.

[7] X. H. Yuan, "An empirical study on the influence of managerial over confidence on corporate investment," Wuhan University of Technology, Wuhan, China, 2007

[8] H. Zhang, "Managerial over confidence and over investment behavior of enterprises," M.S. thesis, Nanjing University of Aeronautics \& Astronautics, Nanjing, China, 2011.

[9] H. Cheng and C. Q. Qu, "The exploration of managers' over confidence," Finance and Taxation, vol. 1, pp. 59, 2010.

[10] S. X. Wu and C. H. Zhang, "The problem of excessive investment in listing Corporation," Special Zone Economics, pp. 90-91, 2009.

[11] P. Cui, "A study on the investment shortage and over investment of Chinese listing Corporation," Jinan University, Guangzhou, China, 2006.

[12] T. Ran, "Research on the excessive investment behavior of the listing Corporation based on the free cash flow hypothesis," Shandong University, Shandong, 2009.

[13] S. A. Richardson, "Over-investment of free cash flow," Review of Accounting Studies, 2006.

[14] C. Polk and P. Sapienza, "The real effects of investor sentiment," presented at the AFA DC Meetings, Washington, USA, 2003.

[15] Q. L. Dai, "Research on the dividend policy of Chinese listing Corporation from the perspective of managerial over confidence," South China University of Technology, Guangzhou, China, 2011.

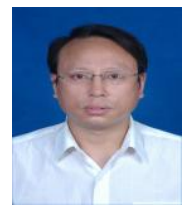

Xiao Longjie was born in September 1966 in Jiangsu jianhu. In June 1991 graduated at Yangzhou University, Department of physics, won the science bachelor's degree, is located in Yangzhou, China; 2001 graduation in Southeast University majoring in economics and management, to obtain a master's degree in management science, Southeast University in Nanjing, China, December 2011 graduation in Management Department of Southeast University Science and engineering, management science doctorate. Major research projects in financial engineering.

He took part in the work in August 1991, as a middle school teacher. In June 2001 he entered the school of Humanities and Social Sciences, Nanjing University of Aeronautics and Astronautics, August 2006 into the College of economics and management; Nanjing University of Aeronautics and Astronautics, he is an associate professor of economics. The main results of this paper, the financial innovation of science and technology development research -- key factors based on DEMATEL system analysis "(the modern management science, Nanjing, China), the Jiangsu Province private listed company capital structure and the performance of the empirical research (Journal of Journal of Southeast University, Nanjing, China), and so on

Dr. Xiao Longjie, to participate in the China Aviation society, as a member of the Ministry of education, the Ministry of education and graduate education development center, communications experts.

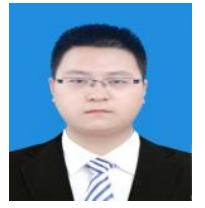

Zhou Anfeng was born in February 1991 in Jiangsu Yancheng. In June 2008 graduated from the School of Economics and Management, Nanjing University of Aeronautics \& Astronautics, is located in Nanjing, China; now is a graduate student of economics and Management School of Nanjing University of Aeronautics \& Astronautics. The main research direction is corporate finance.

He took part in the work in August 2012, in a manufacturing enterprise engaged in financial work. He is working in an investment consulting company in 2015 , as an intern. The main results of this paper, "Study on accelerating the construction of home care for the elderly in Bixi" (Theoretical Research, Suzhou, China). 